\title{
PENERAPAN MODEL MAKE A MATCH BERBANTUAN MEDIA UNTUK MENINGKATAN MOTIVASI DAN HASIL BELAJAR IPS
}

\author{
Krisno Prastyo Wibowo, Marzuki \\ SMP Negeri 2 Batealit Jepara, Universitas Negeri Yogyakarta \\ krisnoprastyo@gmail.com, marzukiwafi@yahoo.co.id
}

\begin{abstract}
Abstrak
Penelitian ini bertujuan untuk meningkatkan motivasi dan hasil belajar IPS. Subjek penelitian ini adalah siswa kelas VIII A SMP Negeri 2 Batealit Jepara, tahun pelajaran 2013/2014 yang terdiri atas 23 siswa. Teknik pengumpulan data yang digunakan adalah: (1) observasi, untuk mengumpulkan data motivasi siswa, (2) tes, berupa soal objektif untuk mengukur kemampuan kognitif siswa yang diperoleh dalam pembelajaran IPS dengan model make a match, (3) dokumentasi, untuk mengumpulkan semua catatan penting yang berhubungan dengan penelitian dan (4) wawancara, untuk mendapatkan data tentang deskripsi pembelajaran di kelas dan permasalahan yang dihadapi. Teknik analisis data menggunakan analisis deskriptif kuantitatif.

Hasil penelitian ini adalah sebagai berikut: (1) Terjadi peningkatan motivasi belajar siswa, siklus I dengan rata-rata 75,91 (baik), dan pada siklus II meningkat menjadi 78,17 (baik), (2) peningkatan hasil belajar pada siklus I nilai rata-rata 68,70 dan persentase ketuntasan belajar 52,17\%. Pada siklus II meningkat menjadi 75,65 dan persentase ketuntasan belajar juga meningkat menjadi $86,96 \%$. Dengan demikian, penerapan model make a match berbantuan media video dapat meningkatkan motivasi dan hasil belajar siswa di SMP negeri 2 Batealit Jepara.
\end{abstract}

Kata kunci: model make a match, media, motivasi, hasil belajar

\section{THE APPLICATION OF MAKE A MATCH MODEL ASSISTED BY MEDIA TO INCREASE MOTIVATION AND LEARNING OUTCOME OF SOCIAL STUDIES}

\author{
Krisno Prastyo Wibowo, Marzuki \\ SMP Negeri 2 Batealit Jepara, Universitas Negeri Yogyakarta \\ krisnoprastyo@gmail.com, marzukiwafi@yahoo.co.id
}

\begin{abstract}
The main purpose of this research is to increase student's motivation and learning outcome of social studies. The Subjects in this research were students of Class VIII A in SMP Negeri 2 Batealit Jepara in the academic year of 2013/2014 consisting of 23 students. The technique of collecting data that was used was: (1) observation, to collect data of student's motivation, (2) a test which formed objective questions to measure students' cognitive abilities acquired in learning social studies by Make a Match model, (3).documentation, to collect all important records that have coleration with the research and (4) interview, to get information about the description of study in the class and the problem encountered. The data analysis technique used descriptive quantitative analysis. There are the result of this research: (1) There is an increase of student's motivation in learning, phase I with an average of 75.91 (good), and phase II rises up to 78.17 (good), (2) learning outcome increase in phase I has an average score of 68.70 and percentage of passing grade is $52.17 \%$. In phase II it increases up to 75.65 and percentage of passing grade also increases to $86.96 \%$. Thus the implementation of Make a Match model assisted by film media can improve student's motivation in learning and learning outcome in SMP Negeri 2 Batealit Jepara.
\end{abstract}

Keywords: make a match model, media, motivation, learning outcome 



\section{Pendahuluan}

Pembelajaran IPS merupakan bagian dari fungsi sekolah untuk memelihara martabat masyarakat melalui penanaman nilai. Fokus pembelajaran IPS adalah nilai kemanusiaan dalam suatu pranata dan kontribusi antara manusia dengan manusia, maupun dengan lingkungannya. Penekanan IPS diarahkan guna membantu peserta didik mengembangkan kompetensi dan sikap sebagai warga negara, yakni bagaimana peserta didik belajar hidup dalam masyarakat yang bernegara. Pembelajaran IPS memiliki tujuan untuk membantu siswa mecapai keberhasilan berpartisipasi dalam kehidupan bermasyarakat, sedangkan program pembelajaran IPS yang komprehensif adalah program yang mencakup empat dimensi yakni: (1) pengetahuan, (2) keterampilan, (3) sikap dan nilai, serta (4) tindakan (Sapriya, 2009, p.48). Keempat dimensi ini memiliki karakteristik tersendiri yang berbeda satu sama lain, namun dalam proses pembelajaran empat dimensi ini saling melengkapi.

Pembelajaran IPS seharusnya melibatkan peserta didik secara aktif untuk berinteraksi selama proses pembelajaran berlangsung. Hal ini juga berarti bahwa pembelajaran IPS harus berpusat pada peserta didik. Pembelajaran IPS harus menarik serta memenuhi prinsip-prinsip pembelajaran. Proses pembelajaran merupakan kegiatan yang kompleks. Oleh sebab itu untuk menjadi guru IPS yang berhasil harus memiliki sejumlah kompetensi. Salah satu kompetensi penting bagi guru, yaitu menguasai model-model pembelajaran sebagai sarana untuk mendorong keterlibatan peserta didik dalam proses pembelajaran, sehingga dapat meningkatkan hasil belajar.

Beberapa kelemahan pembelajaran IPS selama ini di antaranya adalah guru tidak mengembangkan berbagai metode dan model pembelajaran, kurangnya mengikutsertakan peserta didik dalam proses pembelajaran serta hanya menggunakan metode ceramah atau ekspositori. Hal tersebut menyebabkan gairah belajar dan motivasi siswa menjadi rendah. Pada umumnya pendidik memulai kegitan belajar dengan bercerita kemudian memompakan bahan yang telah diketahuinya itu kepada peserta didik. Pendidik hanya menuntut peserta didik untuk mendengarkan dengan tertib, kemudian menghafalkannya di rumah (Sudjana, 2000, p. 27).
Para guru IPS hendaknya berupaya mewujudkan proses pembelajaran IPS yang aktif, kreatif, efektif, dan menyenangkan. Dengan menggunakan model pembelajaran make a match, diharapkan keaktifan dan kekreatifan siswa akan terbentuk, sehinggga proses pembelajaran menjadi efektif dan menyenangkan. Apabila hal-hal tersebut telah terjadi maka motivasi belajar siswa dalam belajar dapat meningkat.

Proses Pembelajaran IPS yang digunakan di SMP.N 2 Batealit, Jepara adalah pembelajaran yang berpusat pada guru (teacher centered). Penggunaan metode tersebut cende-rung akan membuat peserta didik bosan dan tidak termotivasi untuk aktif dalam kegiatan pembelajaran karena selama pembelajaran guru banyak memberikan ceramah untuk mengejar ketercapaian materi. Tidak adanya variasi penggunaan model pembelajaran juga menjadi salah satu pemicu munculnya masalah-masalah tersebut. Aktivitas yang dilakukan peserta didik biasanya hanya mendengar dan mencatat yang berakibat pada siswa mempunyai tingkat kebosanan yang tinggi dalam mengikuti pelajaran IPS karena peserta didik jarang bertanya, mengemukakan pendapat atau melakukan aktivitas fisik.

Kegiatan yang melibatkan kerja sama dan interaksi langsung antar peserta didik jarang dilakukan, sehingga komunikasi antar peserta didik maupun antar peserta didik dengan guru masih belum terjalin selama proses pembelajaran. Hal tersebut berdampak pada hasil belajar siswa kelas VIII.A yang rendah dilihat dari rata-rata nilai siswa yaitu 63,91 pada ulangan harian pertama (masih di bawah KKM yang telah ditetapkan sekolah yaitu 68).

Berbagai macam permasalahan pembelajaran IPS di SMP Negeri 2 Batealit, Jepara tersebut terkait pemanfaatan model pembelajaran yang kurang bervareasi, media pembelajaran yang digunakan, sehingga motivasi belajar dan hasil belajar IPS rendah. Oleh karena itu, perlu dilakukan suatu tindakan yang terkait dengan model pembelajaran dan media pembelajaran yang mampu meningkatkan motivasi dan hasil belajar IPS. Salah satu upaya tersebut ialah melakukan/ menerapkan model make a match berbantuan media untuk meningkatkan motivasi dan hasil belajar IPS. Melalui penerapan model pembelajaran make a match berbantuan media pada pembelajaran IPS, diharapkan dapat 
mendorong peserta didik untuk memiliki motivasi belajar yang baik, dengan demikian hasil belajar IPS di juga dapat meningkat.

Model pembelajaran make a match bisa diterapkan untuk semua mata pelajaran dan tingkatan kelas. Metode ini sangat disenangi siswa lantaran tidak menjemukan karena guru memancing kreativitas siswa dengan menggunakan media. Menurut Suprijono (2009, pp.94-95), hal-hal yang perlu dipersiapkan sebelum memulai pembelajaran ini adalah kartu-kartu. Kartu-kartu tersebut terdiri dari kartu-kartu pertanyaan dan kartu-kartu berisi jawaban dari pertanyaan tersebut. Pendapat tersebut sejalan dengan teknik belajar mengajar mencari pasangan (make a match) yang dikembangkan oleh Lorna Curran. Teknik ini merupakan teknik belajar yang menarik untuk digunakan dalam mengulang materi yang telah diberikan sebelumnya. Teknik baru juga bisa diajarkan dengan strategi ini dengan catatan bahwa siswa diberi tugas mempelajari topik yang akan diajarkan terlebih dahulu, sehingga ketika masuk kelas mereka sudah memiliki bekal pengetahuan akan bahan ajar yang akan dipelajari. Adapun Langkah-langkahnya adalah sebagai berikut (Lie, 2007, pp.55-56): (1) Guru menyiapkan beberapa kartu yang berisi beberapa konsep atau topik yang cocok untuk sesi review (persiapan menjelang tes atau ujian); (2) setiap siswa mendapat satu buah kartu; (3) setiap siswa mencari pasangan yang mempunyai kartu yang cocok dengan kartunya. Misalnya, pemegang kartu yang bertuliskan LIMA akan berpasangan dengan kartu PERU. Atau pemegang kartu yang berisi nama KOFI ANNAN akan berpasangan dengan pemegang kartu SKRETARIS JENDERAL PBB; (4) Siswa bisa juga bergabung dengan dua atau tiga siswa lain yang memegang kartu yang cocok. Misalnya, pemegang kartu 3+9 akan membentuk kelompok dengan pemegang kartu 3x4 dan 6x2.

Selain dengan menerapkan model make a match dalam pembelajaran, penggunaan media untuk meningkatkan motivasi dan hasil belajar juga sangat diperlukan. Sebab pembelajaran yang menggunakan media pembelajaran yang sesuai akan memberikan manfaat yang sangat besar dalam proses pembelajaran.

Menurut Sudjana \& Rivai (1992, p.2) manfaat penggunaan media pembelajaran adalah sebagai berikut. Pertama, pembelajaran akan lebih menarik perhatian siswa sehingga motivasi belajar akan tumbuh. Kedua, bahan pembelajaran akan lebih jelas maknanya, sehingga dapat lebih dipahami oleh siswa dan memungkinkannya untuk menguasai dan mencapai tujuan pembelajaran. Ketiga, metode mengajar akan lebih bervariasi, tidak sematamata komunikasi verbal melalui penuturan kata-kata oleh guru, sehingga siswa tidak bosan dan guru tidak kehabisan tenaga. Keempat, siswa dapat lebih banyak melakukan kegiatan belajar, sebab tidak hanya mendengarkan uraian guru, tetapi juga aktivitas lain seperti mengamati, melakukan, mendemonstrasikan, memerankan, dan lain-lain.

Gerlach \& Ely (1980, p.241) menyatakan "A medium, broadly conceived is any person, material, or even that establishes conditions which enable the learner to acquire knowledge, skills, and attitudes". Artinya secara umum media meliputi orang, bahan, peralatan atau kegiatan yang menciptakan kondisi yang memungkinkan siswa memperoleh pengetahuan, keterampilan, dan sikap. Dalam pengertian tersebut media bukan hanya alat perantara akan tetapi juga meliputi manusia sebagai sumber belajar, kegiatankegiatan yang dikondisikan untuk menambah pengetahuan dan wawasan, mengubah sikap siswa, atau untuk menambah keterampilan.

Media pembelajaran mempunyai kontribusi yaitu: penyampaian pesan pembelajaran dapat lebih terstandar, menarik, interaktif. Dengan menerapkan media pembelajaran, waktu pelaksanaan pembelajaran dapat diperpendek, kualitas pembelajaran dapat ditingkatkan, proses pembelajaran dapat berlangsung kapanpun dan dimanapun diperlukan, sikap positif siswa terhadap materi pembelajaran serta proses pembelajaran dapat ditingkatkan, dan peran guru berubah ke arah yang positif. Dengan demikian suatu media pembelajaran harus dapat berfungsi untuk kepentingan pembelajaran, berperan menggantikan fungsi dan tugas-tugas dalam pembelajaran, sehingga bisa memberi man-faat lebih bagi siswa.

Upaya untuk meningkatkan hasil belajar tersebut, harus diawali dengan meningkatkan motivasi siswa dalam pembelajaran. Peningkatan motivasi siswa juga perlu dilakukan agar siswa mau melibatkan diri secara aktif dalam pembelajaran. Apabila sis- 
wa aktif dalam belajar, maka siswa akan lebih menguasai materi pelajaran. Dengan demikian siswa dapat memperoleh hasil belajar yang lebih baik.

Tahap-tahap dalam pembelajaran model make a match mengharuskan siswa terlibat aktif dalam pembelajaran. Dengan aktivitas belajar yang tinggi menunjukkan tingginya motivasi belajar yang dimiliki dan memungkinkan siswa untuk menguasai materi pelajaran dengan lebih baik, sehingga dapat mencapai hasil belajar yang lebih baik. Penerapan pembelajaran model make a match juga dimaksudkan untuk meningkatkan motivasi belajar siswa terhadap pembelajaran IPS. Motivasi adalah kunci dalam belajar, siswa harus memiliki motivasi yang tinggi untuk mendapatkan pengalaman belajar dalam upaya memperoleh pengetahuan.

Menurut Elliot, et al (2000, p.332) "motivation is defined as an internal state that arouses us to action, pushes us in particular directions, and keeps us engage in certain activities". Pernyataan tersebut mengandung arti bahwa motivasi adalah suatu keadaan internal yang membangkitkan kita untuk cenderung bertindak dan mendorong kita untuk mencapai arah tertentu. Belajar dan motivasi sama-sama penting dalam proses keberhasilan. Belajar memungkinkan siswa untuk mempero-leh pengetahuan serta keterampilan baru dan motivasi memberikan dorongan untuk menunjukkan apa yang telah kita pelajari. Pernyataan tersebut sejalan dengan pendapat Santrock (2008, p. 510) yang menyatakan bahwa motivasi adalah suatu proses yang diberikan kepada siswa untuk memberikan semangat, arah, dan kegigihan perilaku. Hal tersebut berarti perilaku yang termotivasi adalah perilaku yang penuh energi, terarah, dan bertahan lama.

Sardiman (2008, p.73), mengartikan motif sebagai daya upaya yang mendorong seseorang untuk melakukan sesuatu. Motif dapat dikatakan sebagai daya penggerak dari dalam subjek untuk melakukan aktivitasaktivitas tertentu demi mencapai suatu tujuan. Beliau juga mengatakan bahwa kaitannya dengan kegiatan belajar, motivasi dapat dikatakan sebagai keseluruhan daya penggerak di dalam diri siswa yang menimbulkan, menjamin kelangsungan dan memberi arah kegiatan belajar, sehingga tujuan yang diharapkan oleh subjek belajar dapat dicapai.
Motivasi merupakan suatu kondisi yang menggerakkan peserta didik agar mampu mencapai tujuan dari motifnya. Motivasi adalah kekuatan yang ada dalam diri seseorang yang menyebabkan orang tersebut mempunyai inisiatif untuk melakukan sesuatu dan berperilaku tertentu. Kebutuhan dan tujuan merupakan dua hal yang penting dilakukan untuk dapat memotivasi seseorang. Kebutuhan adalah kondisi yang dialami seseorang berkaitan dengan kelangkaan tentang sesuatu pada situasi/saat tertentu. Peserta didik tidak akan memiliki kebutuhan ketika tidak ada tujuan yang ingin dicapai dan tujuan tidak akan memotivasi peserta didik ketika peserta didik tidak melihat adanya kebutuhan untuk mencapai tujuan. Hal ini senada dengan yang dikemukakan oleh Hamalik (2004, p.173), "Motivasi adalah suatu perubahan energi di dalam pribadi seseorang yang ditandai dengan timbulnya afektif dan reaksi untuk mencapai tujuan", sedangkan tujuan adalah kondisi ideal yang diinginkan yang akan memberikan manfaat untuk memuaskan kebutuhan.

Situasi yang menyebabkan perubahan peserta didik terdiri dari dua aspek yaitu motivasi intrinsik dan motivasi ekstrinsik. Motivasi intrinsik ialah kondisi yang berada dalam diri peserta didik yang berwujud kebutuhan, sedangkan motivasi ekstrinsik ialah aspek yang berada di luar peserta didik yang berwujut perangsang atau tujuan. Dengan demikian, untuk memahami prinsip-prinsip motivasi ini harus diperhatikan kedua aspek tersebut (Sardiman, 2008, pp.89-90). Motivasi belajar dapat timbul karena faktor dari dalam merupakan motivasi yang timbul dari dalam diri seseorang berupa hasrat, keinginan berhasil dan dorongan kebutuhan belajar, harapan akan cita-cita. Sedangkan faktor dari luar merupakan motivasi yang timbul akibat ada rangsangan dari luar diri seseorang seperti penghargaan, lingkungan belajar yang kondusif, dan kegiatan belajar yang menarik. Tetapi harus diingat, kedua faktor tersebut disebabkan oleh rangsangan tertentu, sehingga seseorang berkeinginan untuk melakukan aktivitas belajar yang lebih giat dan bersemangat .

Motivasi juga merupakan suatu proses, yang mana proses tersebut dapat: (1) membimbing anak didik kita kearah pengalaman-pengalaman, dimana kegiatan itu dapat berlangsung; (2) memberikan kepada anak didik kita kekuatan, aktivitas dan kewaspada- 
an yang memadai; (3) pada suatu saat mengarahkan perhatian mereka terhadap suatu tujuan (Sutadipura, 1996, p.114).

Dari pendapat-pendapat tersebut, dapat diambil kesimpulan bahwa seseorang melakukan sesuatu karena adanya dorongan dalam dirinya untuk mencapai sesuatu. Makin kuatnya dorongan tersebut maka makin besar pula upaya yang dilakukannya agar sesuatu yang dituju dapat tercapai, sebab apabila sesuatu yang diinginkan itu dapat tercapai maka ia akan merasa berhasil dan akan merasa puas.

Menurut Sardiman, (2008, p.92) ada beberapa bentuk dan cara untuk menumbuhkan motivasi peserta didik, yaitu: memberikan angka (nilai), memberi hadiah, membuat persaingan/kompetensi, menjaga harga diri, memberi ulangan, mengumumkan hasil belajar peserta didik, memberi pujian, memberi hukuman, meningkatkan hasrat untuk belajar, mendorong minat, serta tujuan yang diakui. Dengan demikian, makin jelas bahwa tugas guru harus senantiasa mampu untuk mencoba menganalisis, memahami, menguji coba, bahkan mengelaborasikan ke semua unsur tersebut yang banyak berpengaruh dalam membangkitkan motivasi peserta didik untuk mengikuti proses pembelajarannya. Akan tetapi yang harus menjadi catatan tidak setiap siswa sama akan merespon terhadap semua unsur motivasi di atas, karena masing-masing peserta didik akan sangat tergantung dari segi kematangannya dalam mengikuti proses pembelajaran baik secara pisik maupun psikis. Oleh karenanya, guru harus jeli, sadar, dan penuh tanggung jawab dalam menjalankan program pengajarannya. Hal yang menarik dari penjelasan tersebut adalah bahwa motivasi belajar siswa juga bisa tumbuh apabila gurunya mampu menggunakan berbagai macam bentuk mengajar, termasuk di dalamnya memiliki keterampilan yang cukup untuk mempraktekkan berbagai pendekatan dalam pelaksanaan proses pembelajaran.

Dalam kaitannya dengan pengertian belajar maka motivasi belajar adalah keseluruhan daya penggerak di dalam diri peserta didik yang menimbulkan kegiatan belajar mengajar, menjamin kelangsungan kegiatan belajar untuk mencapai suatu tujuan belajar. Maka menurut Sardiman, (2008, p.85) motivasi mempunyai beberapa fungsi di antaranya: (1) mendorong manusia untuk berbuat, jadi sebagai penggerak atau motor yang me- lepaskan energi. Motivasi dalam hal ini merupakan penggerak dari setiap kegiatan yang akan dikerjakan; (2) menentukan arah perbuatan, yakni kearah tujuan yang hendak dicapai. Dengan demikian motivasi dapat memberikan arah dan kegiatan yang harus dikerjakan; (3) menyeleksi perbuatan, yakni menentukan perbuatan-perbuatan apa yang harus dikerjakan yang serasi guna mencapai tujuan, dengan menyisihkan perbuatan yang tidak bermanfaat bagi tujuan tersebut.

Dengan memperhatikan pendapat tersebut maka dapat digambarkan bahwa di antara fungsi motivasi dalam proses belajar adalah: Mendorong timbulnya kelakuan atau suatu perbuatan, seperti timbulnya dorongan untuk belajar, motivasi berfungsi sebagai pengarah, artinya mengarahkan perbuatan kepencapaian tujuan yang diinginkan, motivasi berfungsi sebagai penggerak, artinya besar kecilnya motivasi akan menentukan cepat atau lambatnya suatu perbuatan.

Macam-macam motivasi menurut Sardiman, (2008, p.86) dilihat dari dasar pembentukannya terdiri dari: (1) motif bawaan; adalah motif yang dibawa sejak lahir, motif itu ada tanpa dipelajari seperti dorongan untuk makan, minum, bekerja, istirahat, seksual. Motif ini sering disebut dengan motif yang disyaratkan secara biologis, (2) motif yang dipelajari; maksudnya motif yang timbul karena dipelajarinya. Seperti dorongan untuk mengajarkan sesuatu di masyarakat. Secara umum, terdapat dua peranan penting motivasi dalam belajar yaitu motivasi merupakan daya penggerak psikis dalam diri siswa yang menimbulkan kegiatan belajar. Selanjutnya, motivasi memegang peranan penting dalam memberikan gairah, semangat dan rasa senang dalam belajar, sehingga peserta didik yang mempunyai motivasi tinggi mempunyai energi yang banyak untuk melaksanakan kegiatan belajar (Nara, 2011, p.51).

Hasil akhir yang dituju dengan pembelajaran model make a match berbantuan media adalah untuk meningkatkan hasil belajar IPS siswa. Hasil belajar terdiri dari dua kata yaitu hasil dan belajar, hasil merupakan sesuatu yang diadakan oleh usaha. Sedangkan belajar merupakan tahapan perubahan tingkah laku siswa yang positif, sebagai hasil interaksi edukatif dengan lingkungan yang diperoleh dari usaha perubahan tingkah laku siswa yang melibatkan proses kognitif (Syah, 2011, p.14) 
Hasil belajar, belajar, dan mengajar merupakan konsep yang tidak bisa dipisahkan. Belajar merujuk pada apa yang harus dilakukan seseorang sebagai subyek dalam belajar. Sedangkan mengajar merujuk pada apa yang seharusnya dilakukan seseorang guru sebagai pengajar. Menurut Gagne (1988, p.66) hasil belajar diklasifikasikan ke dalam lima kategori yaitu: informasi verbal, keterampilan intelektual, strategi kognitif, sikap, dan keterampilan motoris.

Mengacu pada kategori hasil belajar tersebut, maka hal itu sejalan dengan pendapat Savage \& Amstrong (1996, p.11) yang menyatakan "for each broad social studies purpose there are three amphases that need to be identified: knowledge, skills and values" (pada setiap tujuan disiplin IPS terdapat tiga penekanan yang dibutuhkan untuk diidentifikasi yaitu pengetahuan, keterampilan dan nilai). Oleh karena itu, dibutuhkan sebuah penilaian yang bisa mengakomodasi ketiga ranah tersebut sehingga menjadi hasil belajar IPS yang bermakna bagi siswa.

Menurut Kennedy, et al (2012, p.5) "Learning outcomes are statements of what a learner is expected to know, understand and/ or be able to demonstrate after completion of a process of learning". Artinya hasil belajar merupakan pernyataan apa yang diharapkan dari siswa sehingga dapat mengetahui, memahami dan menunjukkan kemampuan setelah selesainya proses pembelajaran.

Untuk mewujudkan hasil belajar IPS, diperlukan sebuah penilaian atau evaluasi yang komprehensif. Menurut Sudijono (2011, pp. 31-37), evaluasi hasil belajar dapat dikatakan terlaksana dengan baik apabila dalam pelaksanaanya senantiasa berpegang pada tiga prinsip dasar yaitu: prinsip keseluruhan, prinsip kesinambungan, dan prinsip objektivitas.

Sebagai suatu bidang kegiatan, evaluasi belajar dalam rangka mengukur keberhasilan peserta didik biasanya memiliki ciriciri sebagai berikut: (1) pengukurannya dilakukan secara tidak langsung; (2) pengukurannya pada umumnya menggunakan ukuranukuran yang bersifat kuantitatif, atau lebih sering menggunakan simbol-simbol angka. (3) pengukurannya menggunakan unit-unit atau satuan-satuan yang tetap, itu didasarkan pada teori yang menyatakan bahwa setiap populasi siswa yang sifatnya heterogen jika dihadapkan pada suatu tes hasil belajar maka prestasi belajar yang mereka raih akan terlukis sperti pada kurva normal; (4) prestasi belajar yang dicapai oleh siswa dari waktu ke waktu adalah bersifat relatif atau tidak selalu menunjukkan kesamaan atau keajegan; (5) dalam kegiatan evaluasi hasil belajar sulit dihindari terjadinya kekeliruan pengukuran (error).

Menurut Sudjana (2004, p.22), Hasil belajar adalah kemampuan-kemampuan yang dimiliki siswa setelah menerima pengalaman belajarnya). Sedangkan menurut Horwart Kingsley beliau membagi tiga macam hasil belajar mengajar sebagai berikut: keterampilan dan kebiasaan, pengetahuan dan pengarahan, sikap dan cita-cita. Dari pendapat tersebut dapat disimpulkan bahwa hasil belajar adalah kemampuan keterampilan, sikap dan keterampilan yang diperoleh peserta didik setelah ia menerima perlakuan yang diberikan oleh guru sehingga dapat mengonstruksikan pengetahuan itu dalam kehidupan sehari-hari.

Menurut Dahar (2004, p.21) menyatakan hasil belajar adalah apa yang telah dapat diciptakan, hasil pekerjaan, hasil yang menyenangkan hati yang diperoleh dengan jalan keuletan kerja. Dari pengertian yang dikemukakan tersebut di atas, jelas terlihat bahwa hasil belajar adalah suatu tujuan yang bisa diperoleh dengan melalui suatu proses yang pada intinya hasil belajar adalah hasil dari suatu kegiatan yang telah dikerjakan, diciptakan, yang menyenangkan hati, dan yang diperoleh dengan jalan keuletan kerja, baik secara individual maupun secara kelompok dalam bidang kegiatan tertentu.

Slameto (2003, p.2) menyatakan bahwa hasil belajar adalah suatu proses usaha yang dilakukan seseorang untuk memperoleh suatu perubahan tingkah laku yang baru secara keseluruhan, sebagai hasil pengalamannya sendiri dalam interaksi dengan lingkungannya. Secara sederhana dari pengertian belajar sebagaimana yang dikemukakan oleh pendapat tersebut, dapat diambil suatu pemahaman tentang hakekat dari aktivitas belajar adalah suatu perubahan yang terjadi dalam diri individu.

Menurut Dimyati \& Mudjiono (1999, pp. 250-251), hasil belajar merupakan hal yang dapat dipandang dari dua sisi yaitu sisi siswa dan guru. Dari sisi siswa, hasil belajar merupakan tingkat perkembangan mental yang lebih baik bila dibandingkan pada saat sebelum belajar. Tingkat perkembangan men- 
tal tersebut terwujud pada jenis-jenis ranah kognitif, afektif, dan psikomotor. Sedangkan dari sisi guru, hasil belajar merupakan saat terselesaikannya bahan pelajaran.

Untuk mewujudkan hasil belajar IPS diperlukan sebuah penilaian yang komprehensif. Mardapi (2008, p.6) berpendapat bahwa penilaian mencakup semua cara yang digunakan untuk menilai unjuk kerja individu, berfokus pada individu yaitu prestasi belajar yang dicapai oleh individu. Penilaian harus mampu mendorong peserta didik belajar lebih baik dan guru untuk mengajar lebih baik. Uno (2010, p.156) mengemukakan indikator keefektifan pembelajaran biasanya diukur dengan tingkat pencapaian siswa yang diketahui setelah mengikuti pembelajaran dan evaluasi.

Dari kedua pendapat tersebut, untuk menentukan peningkatan hasil belajar maka tidak hanya satu faktor saja yang dilihat dari siswa. Tetapi juga harus memperhatikan nilainilai pada faktor-faktor yang lainnya terkait proses yang dilakukan untuk pencapaian nilai tersebut.

Beberapa penelitian tentang penerapan model pembelajaran make a match untuk meningkatkan motivasi dan hasil belajar siswa seperi yang telah dilakukan oleh Febriana (2011); Nurfaidah (2011); dan Huss, John A (2006) menunjukkan bahwa pembelajaran model make a match dapat meningkatkan motivasi dan hasil belajar siswa. Penelitian tentang manfaat penggunaan media pembelajaran yang dilakukan oleh Riyanti \& Heni (2007); Jamalong (2012); Marwiyanto (2007) diperoleh kesimpulan bahwa penggu-naan media pembelajaran dapat meningkatkan keaktifan, serta hasil belajar siswa.

Berdasarkan paparan tersebut tujuan penelitian ini adalah untuk: (1) meningkatkan motivasi belajar siswa. (2) meningkatkan hasil belajar siswa. KKM yang ditetapkan adalah 68, penelitian ini bertujuan untuk meningkatkan ketuntasan hasil belajar siswa sampai 85\% mencapai KKM.

\section{Metode Penelitian}

Metode penelitian yang dipakai adalah penelitian tindakan kelas untuk meningkatkan motivasi dan hasil belajar IPS pada siswa kelas VIII-A semester 2 SMP N 2 Batealit Tahun Pelajaran 2013/2014. Penelitian ini mulai dilaksanakan pada bulan Desem- ber 2013 sampai dengan bulan Maret 2014 di SMP N 2 Batealit, Jepara.

Subjek penelitian ini adalah siswa kelas VIII-A SMP N 2 Batealit, Kabupaten Jepara tahun pelajaran 2013/2014. Siswa kelas VIII-A berjumlah 23 orang, yang terdiri dari 10 laki-laki dan 13 perempuan. Alasan pemilihan kelas ini adalah berdasarkan informasi awal dan wawancara dengan guru IPS yang peneliti lakukan motivasi belajar IPS siswa rendah, siswa lebih sering pasif dalam pembelajaran. Siswa sebagian besar cenderung tidak memperhatikan, mengantuk, dan suka gaduh ketika ketika guru menerangkan. Hasil observasi pratindakan juga ditemukan siswa pasif dalam pembelajaran di kelas dan hasil belajar siswa pada ulangan harian I rendah. Rata-rata hasil ulangan harian pertama kelas VIII-A adalah 63,91. Dari 23 siswa, yang mencapai KKM mata pelajaran IPS sebesar 9 siswa atau 39,13\%. Sedangkan 14 siswa belum mencapai KKM, yaitu sebesar 60,87\%.

Prosedur penelitian tindakan kelas dilaksanakan secara siklus yang berlangsung secara berkesinambungan. Berdasarkan model Kemmis \& Taggart, langkah-langkah penelitian dilaksanakan dalam empat tahap yaitu:

\section{Perencanaan (Planning).}

Pada tahap ini peneliti mempersiapkan silabus, rencana pelaksanaan pembelajaran, lembar kerja siswa, lembar angket motivasi belajar siswa, lembar tes hasil belajar, lembar observasi pelaksanaan model make a match yang kemudian dikonsultasikan dengan dosen pembimbing.

\section{Pelaksanaan Tindakan (Action).}

Dalam tahap ini guru melaksanakan pembelajaran kooperatif model make a match berbantuan media yang disesuaikan dengan materi pembelajaran. Kolaborator berperan untuk melakukan pengamatan pada jalannya pembelajaran

\section{Observasi (Observation).}

Kegiatan ini dilakukan selama proses pembelajaran dengan menggunakan lembar observasi yang telah disiapkan dan mencatat kejadian-kejadian yang tidak terdapat pada lembar observasi dengan membuat lembar catatan lapangan. Hal-hal yang diamati selama 
proses pembelajaran adalah kegiatan pembelajaran dan aktivitas guru maupun siswa selama peleksanaan pembelajaran.

\section{Refleksi (Reflection).}

Kegiatan refleksi digunakan peneliti untuk mengkaji mengenai apa yang telah dilakukan, apa yang telah dihasilkan, apa yang belum dihasilkan, serta kendala apa yang dihadapi selama tindakan untuk melakukan perbaikan pada tindakan berikutnya. Pada tahapan ini, peneliti bersama kolaborator mengadakan evaluasi dan refleksi berkaitan dengan kegiatan pembelajaran yang sudah dilakukan.

Teknik pengumpulan data yang digunakan adalah: (1) observasi, untuk mengumpulkan data motivasi siswa, (2) tes, berupa soal objektif untuk mengukur kemampuan kognitif siswa yang diperoleh dalam pembelajaran IPS dengan model make a match, (3) dokumentasi, untuk mengumpulkan semua catatan penting yang berhubungan dengan penelitian dan (4) wawancara, untuk mendapatkan data tentang deskripsi pembelajaran di kelas dan permasalahan yang dihadapi. Validitas instrumen yang digunakan dalam penelitian ini adalah validitas isi. Validitas isi merupakan validitas yang diestimasi lewat pengujian terhadap isi dengan analisis rasional menurut professional judgment. Data tes hasil belajar digunakan untuk mendapatkan data hasil belajar siswa. Tes hasil belajar yang dirancang adalah tes tertulis berbentuk tes pilihan ganda sebanyak 20 butir soal untuk setiap siklusnya, berisi materi pelajaran yang telah dipelajari siswa. Tes hasil belajar yang digunakan berupa soal test yang diberikan pada akhir siklus.

Teknik analisis data dilakukan secara deskriptif kuantitatif dengan menggunakan nilai rata-rata untuk membandingkan motivasi belajar siswa dan capaian hasil belajar siswa. Analisis deskriptif juga digunakan untuk memberikan gambaran kemajuan proses pembelajaran, yang diperoleh dari data catatan lapangan dan wawancara.

\section{Hasil Penelitian dan Pembahasan}

Penelitian ini menerapkan pembelajaran model make a match berbantuan media yang dilaksanakan selama dua siklus.

\section{Hasil Prasiklus}

Berdasarkan informasi yang diperoleh dari wawancara dengan salah satu guru di SMP Negeri 2 Batealit pelaksanaan pembelajaran IPS belum pernah dilaksanakan dengan menggunakan model pembelajaran make a match dan pembelajaran IPS di kelas VIII.A selama ini berlangsung tradisional dan berpusat pada guru. Guru mendominasi proses pembelajaran dan melakukan sendiri semua aktivitas mengajar tanpa melibatkan siswa, guru hanya menggunakan metode ceramah sehingga siswa bosan mengikuti pembelajaran IPS, guru kurang mempersiapkan pembelajaran IPS dengan baik. Pembelajaran berjalan monoton tanpa aktivitas yang menonjol dari siswa. Siswa tidak diberi kesempatan untuk menyampaikan pendapatnya dalam proses belajar mengajar sehingga siswa takut jika disuruh untuk menjawab pertanyaan. Siswa tidak mengikuti pembelajaran dengan senang hati dan bosan belajar IPS. Pembelajaran berlangsung dengan suasana yang kaku. Kondisi pembelajaran tersebut mengakibatkan hasil belajar siswa dan motivasi belajar siswa menjadi rendah. Hal ini dibuktikan dengan nilai hasil rata rata tes motivasi pra siklus sebesar 65,27 dan rata-rata ulangan harian yang baru mencapai 63,91 .

Hasil belajar siswa pada mata pelajaran IPS di kelas VIII.A SMP Negeri 2 Batealit Jepara belum sesuai yang diharapkan. Sebagian besar siswa Kelas VIII.A belum mencapai ketuntasan belajar. Hanya 8 siswa $(34,78 \%)$ dari 23 siswa yang tuntas belajar atau mencapai KKM sebesar 68 sedang 15 siswa lainnya atau $65,21 \%$ siswa belum tuntas belajar. Nilai rata-rata kelas baru mencapai 63,91.

Tabel 1. Hasil Ulangan IPS Siklus I

\begin{tabular}{lc}
\hline \multicolumn{2}{c}{ Hasil Belajar } \\
\hline Rata-Rata Kelas & 63,91 \\
Nilai Tertinggi & 76 \\
Nilai Terendah & 53 \\
$\geq$ KKM & 8 Siswa $(34,78 \%)$ \\
$<$ KKM & 15 Siswa $(65,21 \%)$ \\
\hline
\end{tabular}

Bersadarkan Tabel 1 tersebut, secara keseluruhan hasil belajar IPS di kelas VIII.A masih tergolong rendah dan belum tuntas karena rata-rata kelas hasil belajar siswa 
masih di bawah KKM yang ditentukan sekolah sebesar 68 .

\section{Hasil Siklus I}

Berdasarkan tes hasil belajar siswa siklus I, terdapat siswa yang mendapat nilai kurang dari $68(\mathrm{KKM}=68)$ sebanyak 11 siswa dengan persentase $47,82 \%$ dan yang mendapat nilai $\geq 68$ sebanyak 12 siswa dengan persentase sebesar 52,17\%, nilai tertinggi 90 , nilai terendah 45 , dan nilai rata-rata kelas yang dicapai adalah 68,70 .

Tabel 2. Hasil Ulangan IPS Siklus I

\begin{tabular}{lc}
\hline \multicolumn{2}{c}{ Hasil Belajar } \\
\hline Rata-Rata Kelas & 68,70 \\
Nilai Tertinggi & 90 \\
Nilai Terendah & 45 \\
$\geq$ KKM & 12 Siswa $(52,17 \%)$ \\
$<$ KKM & 11 Siswa $(47,82 \%)$ \\
\hline
\end{tabular}

Berdasarkan pengamatan terhadap motivasi siswa menggunakan lembar observasi diperoleh hasil yang disajikan pada Tabel 3.

Tabel 3. Observasi Motivasi Belajar Siswa pada Siklus I

\begin{tabular}{|c|c|c|c|c|}
\hline \multirow[t]{2}{*}{ Motivasi belajar siswa } & \multicolumn{2}{|c|}{ Siklus 1} & \multirow[t]{2}{*}{$\mathrm{Jml}$} & \multirow[t]{2}{*}{$\%$} \\
\hline & P1 & P2 & & \\
\hline Tekun & 1 & 1 & 2 & 100 \\
\hline Ulet & 1 & 1 & 2 & 100 \\
\hline Menunjukkan minat & 0 & 1 & 1 & 50 \\
\hline Bekerja mandiri & 1 & 1 & 2 & 100 \\
\hline Cepat bosan & 0 & 1 & 1 & 50 \\
\hline Mempertahankan pendapatnya & 0 & 0 & 0 & 0 \\
\hline Tidak mudah menyerah & 1 & 1 & 2 & 100 \\
\hline Senang memecahkan soal & 0 & 1 & 1 & 50 \\
\hline Rata-rata & 0,5 & 0,87 & 0,69 & 68,75 \\
\hline
\end{tabular}

Dari data tersebut diperoleh hasil persentase nilai motivasi belajar siswa secara keseluruhan sebesar 68,75

Dari data hasil angket motivasi belajar siswa diperoleh hasil rerata nilai motivasi yang diperoleh adalah sebesar 75,91 (kategori baik) dengan perincian sebagai berikut: sebanyak 6 siswa mempunyai motivasi sangat baik dan 17 siswa mempunyai motivasi baik.

\section{Hasil Siklus II}

Nilai hasil tes hasil belajar siswa pada siklus II terdapat siswa yang mendapat nilai kurang dari 68 sebanyak 3 siswa dengan persentase sebesar $13 \%$, sedangkan siswa yang mendapatkan nilai lebih dari 68 sebanyak 20 siswa dengan persentase $87 \%$. Nilai tertinggi 90 , nilai terendah 60 , dan nilai rata-rata kelas yang dicapai adalah 76,65. Dari hasil tes pada siklus II tersebut dapat disimpulkan bahwa hasil belajar pada siklus II telah tercapai karena ketuntasan klasikal mencapai $87 \%$ sedangkan kriteria keberhasilan tindakan yang ditetapkan adalah $85 \%$ dari jumlah siswa. Dengan demikian, hasil belajar IPS telah sesuai dengan indikator ketercapain penelitian.

Tabel 4. Hasil Ulangan IPS Siklus II

\begin{tabular}{lc}
\hline \multicolumn{2}{c}{ Hasil Belajar } \\
\hline Rata-Rata Kelas & 76,65 \\
Nilai Tertinggi & 90 \\
Nilai Terendah & 60 \\
$\geq$ KKM & 20 Siswa $(87 \%)$ \\
$<$ KKM & 3 Siswa $(13 \%)$ \\
\hline
\end{tabular}

Dari data hasil angket motivasi belajar siswa diperoleh hasil rerata nilai motivasi yang diperoleh adalah sebesar 78,18 (kategori baik) dengan perincian sebagai berikut: sebanyak 11 siswa mempunyai motivasi sangat baik dan 12 siswa mempunyai motivasi baik.

Sedangkan berdasarkan pengamatan terhadap motivasi siswa menggunakan lembar observasi diperoleh hasil seperti terlihat pada tabel 5. Dari data tersebut diperoleh hasil persentase nilai motivasi belajar siswa secara keseluruhan sebesar 87,5.

Tabel 5. Observasi Motivasi Belajar Siswa pada Siklus II

\begin{tabular}{|c|c|c|c|c|}
\hline \multirow[t]{2}{*}{ Motivasi belajar siswa } & \multicolumn{2}{|c|}{ Siklus II } & \multirow[t]{2}{*}{ Jml } & \multirow[t]{2}{*}{$\%$} \\
\hline & P1 & P2 & & \\
\hline Tekun & 1 & 1 & 2 & 100 \\
\hline Ulet & 0 & 1 & 1 & 50 \\
\hline Menunjukkan minat & 1 & 1 & 2 & 100 \\
\hline Bekerja mandiri & 1 & 1 & 2 & 100 \\
\hline Cepat bosan & 1 & 1 & 2 & 100 \\
\hline Mempertahankan Pendapatnya & 1 & 0 & 1 & 50 \\
\hline Tidak mudah Menyerah & 1 & 1 & 2 & 100 \\
\hline Senang memecahkan soal & 1 & 1 & 2 & 100 \\
\hline Rata-rata & 0,9 & 0,9 & 0,87 & 87,5 \\
\hline
\end{tabular}




\section{Pembahasan}

Penelitian dilakukan dengan menerapkan dua siklus pembelajaran dengan model yang sama pada tiap siklusnya, yaitu model make a match berbantuan media. Dari hasil analisis hasil belajar siswa yang diperoleh dari pelaksanaan tes evaluasi dengan 20 soal pilihan ganda yang diberikan kepada siswa di setiap akhir siklus yang diterapkan pada proses pembelajaran terbukti mampu meningkatkan hasil belajar siswa. Peningkatan nilai hasil belajar siswa dapat dilihat pada Tabel 5 dan grafik pada Gambar 1.

Tabel 6. Rekapitulasi Peningkatan Hasil Belajar Siswa Pra Siklus, Siklus I, Siklus II

\begin{tabular}{lccc}
\hline \multirow{2}{*}{ Uraian Nilai } & \multicolumn{3}{c}{ Hasil belajar } \\
& Pratindakan & S. I & S II \\
\hline Terendah & 53 & 45 & 60 \\
Tertinggi & 76 & 90 & 90 \\
Rata-Rata & 63,91 & 68,70 & 75,65 \\
Ketuntasan & 8 & 12 & 20 \\
Persen Ketuntasan & $34,78 \%$ & 52,17 & 86,96 \\
\hline
\end{tabular}

Pada tabel 5 tersebut, pencapaian nilai rata-rata hasil tes tiap siklus mengalami peningkatan. Hal ini terlihat dari nilai rata-rata belajar yang dicapai oleh siswa pada tiap siklusnya. (1) rata-rata tes pada siklus I meningkat 5\% dibandingkan dengan pra tindakan; (2) Rata-rata tes pada siklus II meningkat $7 \%$ dibandingkan tes pada siklus I.

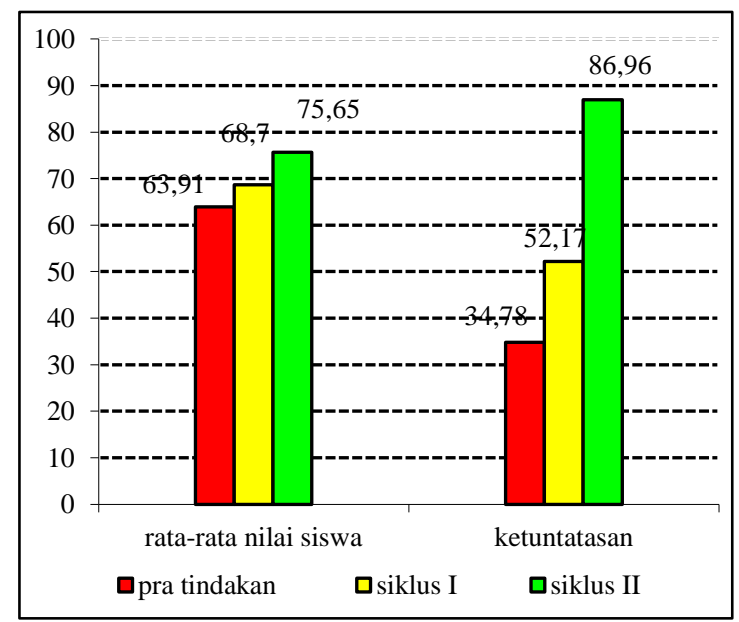

Gambar 1. Peningkatan Hasil Belajar Siswa Pra Tindakan, Siklus I, Siklus II

Berdasarkan Gambar 1 tersebut, dalam penerapan model pembelajaran kooperatif make a match terdapat beberapa temuan penting diantaranya adalah sebagai berikut. Pertama, secara umum hasil belajar siswa sudah meningkat dari pratindakan, siklus pertama hingga siklus kedua, jika dilihat pada gambar 1 menunjukkan bahwa pada pra tindakan ratarata hasil belajar siswa sebesar 63,91, kemudian siklus I rata-rata hasil belajar siswa sebesar 68,70 sedangkan pada siklus II nilai ratarata kelas sebesar 75,65. Hal ini dapat menjadi salah satu indikator keberhasilan dari proses pembelajaran dengan menerapkan model pembelajaran kooperatif dengan model make a match berbantuan media.

Kedua, ketuntasan belajar siswa secara klasikal pada pratindakan sebesar $34,78 \%$, ulangan harian siklus I meningkat dengan persentase $52,17 \%$ selanjutnya pada siklus II mengalami peningkatan dengan persentase $86,96 \%$ yang tuntas, maka secara klasikal siklus II dapat dikatakan tuntas. Hal ini sesuai dengan kriteria keberhasilan awal dimana kelas sudah dikatakan tuntas apabila jumlah siswa yangmendapat nilai 68 atau lebih mencapai $\geq 85 \%$ dari jumlah siswa seluruhnya.

Hasil penelitian menunjukkan bahwa pembelajaran dengan menggunakan model make a match berbantuan media dalam pembelajaran IPS berpengaruh terhadap motivasi belajar siswa. Hal ini dapat diketahui dari peningkatan hasil rata-rata angket motivasi belajar siswa dalam pembelajaran IPS pada materi terkait. Peningkatan motivasi belajar siswa berdasarkan hasil analisis angket motivasi yang diberikan pada siswa dapat dilihat pada Gambar 2.

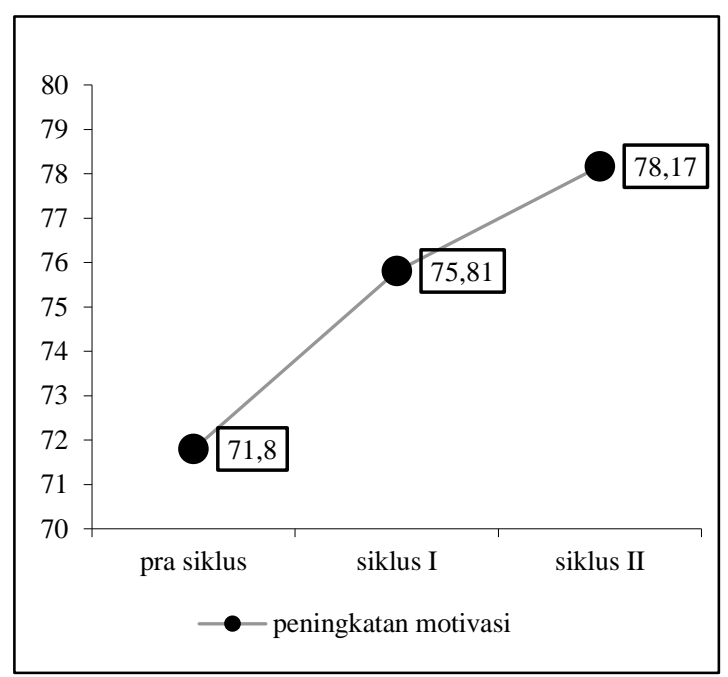

Gambar 2. Peningkatan Motivasi Belajar IPS Pra Siklus, Siklus I, Siklus II

Harmoni Sosial Jurnal Pendidikan IPS Volume 2, No 2, September 2015 
Rata-rata nilai motivasi siswa berdasarkan angket motivasi pada prasiklus sebesar 71,8, pada siklus I sebesar 75,81 dalam dan pada siklus II dengan rata-rata 78,17. memenuhi kriteria keberhasilan tindakan dengan terjadi adanya peningkatan dari prasiklus, siklus I, dan siklus II.

\section{Simpulan dan Saran}

Simpulan

Berdasarkan hasil penelitian dan pembahasan yang diperoleh selama penerapan model pembelajaran make a match berbantuan media pada pembelajaran IPS di kelas VIII A SMP Negeri 2 Batealit Kabupaten Jepara dapat disimpulkan sebagai berikut. Pertama, penerapan model pembelajaran Make A Match berbantuan media terbukti dapat meningkatkan motivasi belajar IPS peserta didik. Nilai rata-rata motivasi belajar IPS pada siklus II sebesar 78.17, atau mengalami peningkatan sebesar 2.26 dari siklus sebelumnya.

Kedua, penerapan model pembelajaran make a match berbantuan media dapat meningkatkan hasil belajar. Nilai rata-rata hasil belajar pada siklus II sebesar 76,65 dan ketuntasan belajar klasikal 86,96\%. Ketiga, Penggunaan media video dapat meningkatkan ketertarikan siswa belajar IPS sehingga proses pembelajaran IPS menjadi lebih menyenangkan dan bermakna. Media video juga mempermudah siswa untuk memahami materi pelajaran IPS.

Saran

Berdasarkan urain dari hasil penelitian dan pembahasan serta simpulan yang telah disampaikan, maka beberapa saran yang dapat diberikan adalah sebagai berikut.

Pertama, saran untuk guru adalah: (1) memberi keleluasaan penuh kepada peserta didik untuk mengeksplor segenap kemampuannya serta semua bentuk keingintahuannya untuk diungkapkan dalam bentuk pencarian, diskusi, dan bekerjasama dengan siswa lainnya; (2) membuat perencanaan yang lebih matang, artinya Guru juga harus memperjelas langkah-langkah model pembelajaran kooperatif model make a match sesuai dengan waktu yang ditetapkan dan guru juga lebih memantau dan membimbing jalannya pembelajaran dengan menggunakan metode pembel- ajaran kooperatif model make a match; (3) lebih kreatif dalam membuat, dan menggunakan media pembelajaran yang sesuai dengan materi pelajaran agar suasana pembelajaran lebih menyenangkan.

Kedua, Kepada institusi sekolah disarankan untuk: (1) menyebarluaskan metode pembelajaran kooperatif model make a match kepada guru-guru mata pelajaran lainnya, karena dengan menggunakan model ini terbukti dapat meningkatkan motivasi belajar siswa di dalam kelas; (2) apat menciptakan budaya meneliti di sekolah dalam rangka untuk pengembangan profesi guru.

Ketiga, Kepada peneliti lain yang ingin melakukan penelitian sejenis hendaknya terlebih dahulu menganalisis model dan media untuk disesuaikan dengan penerapannya, terutama dalam hal alokasi waktu, fasilitas pendukung, media pembelajaran, dan karakteristik siswa yang ada pada sekolah tempat penelitian tersebut dilakukan. Dengan demikian, diharapkan hasil penelitian yang dilakukan akan lebih baik.

\section{Daftar Pustaka}

Dahar, R.W. (2011). Teori-teori belajar dan pembelajaran. Jakarta: Erlangga.

Dimyati \& Mudjiono. (2010). Belajar dan pembelajaran. Jakarta: Rineka Cipta.

Elliot, S.N, et.al. (2000). Educational psychology. USA: Mc Graw Hill.

Febriana, A. (2011). "Penerapan model pembelajaran kooperatif tipe make a match untuk meningkatkan kualitas pembelajaran IPS siswa kelas V SDN kalibanteng Kidul 01 Kota Semarang" [versi elektronik]. Jurnal Kependidikan Dasar, 1, 151-161.

Gagne, R.M. (1988). Prinsip-prinsip belajar untuk pengajaran (Essential of Learning or Instruction). Surabaya: Usaha Nasional.

Gerlach, R, et.al. (1980). Teaching and media. New York: Prentice-Hall.Inc, Englewood Cliffs.

Hamalik, O. (2004). Psikologi belajar dan mengajar. Bandung: Sinar Baru Algensindo. 
Huss, John A (2006). "Gifted Education And Cooperative Learning: A Miss Or A Match". ProQuest Journal Vol 29 No.4.

Jamalong, A. (2012) "Meningkatkan hasil belajar siswa melalui model kooperatif numbered heads together (NHT) di kelas X SMA N 1 Bedui Kabupaten Sanggau". Jurnal Pendidikan \& Kebudayaan, 18, 394-411.

Kennedy, et al. (2012).Writing and using learning outcomes:a practical guide. Diambil pada tanggal 24 April 2014 dari

http://sss.dcu.ie/afi/docs/bologna/writi ng_and_using_learning_out comes. pukul $20.00 \mathrm{wib}$

Lie, A. (2008). Cooperative learning: Mempraktekkan cooperative learning di ruang ruang kelas. Cetakan VI. Jakarta: Grasindo.

Mardapi, D. (2008). Teknik penyusunan instrumen tes dan nontes. Yogyakarta: Mitra Cendikia.

Marwiyanto. (2007). "Keefektifan pembelajar pendidikan matematika dengan model kooperatif dan konvensional ditinjau dari motivasi belajar mahasiswa di PGSD FKIP UNS Surakarta". Jurnal Varia Pendidikan, 19, 109-118.

Nara, H. (2011). Teori belajar dan Pembelajaran. Bogor: Ghalia Indonesia

Nurfaidah (2011). "Mengoptimalkan keaktifan siswa dalam pembelajaran sejarah melalui cooperative learning dengan model make a match: penelitian tindakan kelas di SMA Negeri 4 Palu". Jurnal PTK DBE, vol.1 tahun 2011.
Riyanti \& Suryani, H. (2007). "Variasi media dalam meningkatkan aktivitas dan hasil belajar sains." Jurnal Forum Kependidikan, 26, 198-209.

Santrock, W.J. (2007). Psikologi pendidikan. Jakarta: Kencana Prenada Group.

Sapriya. (2009). Pendidikan IPS. Bandung: PT Remaja Rosdakarya.

Sardiman, A.M. (2008). Interaksi \& motivasi belajar mengajar. Jakarta: Rajawali Pers.

Savage, T.V., \& Amstrong, D.G. (1996). Effective teaching in elementary social studies $\left(3^{\text {rd }}-e d\right)$. New Jersey: Prentice-Hall, Inc.

Slameto. (2010). Belajar dan faktor-faktor yang mempengaruhinya. Jakarta: Rineka Cipta.

Sudijono, A. (2011). Pengantar evaluasi pendidikan. Jakarta: Raja Grafindo.

Sudjana, N \& Rivai, A. (1992). Media pengajaran. Bandung: Sinar Baru.

Sudjana, N. (2009). Penilaian hasil proses belajar mengajar. Bandung: Remaja Rosda Karya.

Sudjana, S. (2000). Strategi Pembelajaran. Bandung: Falah Production.

Suprijono, A. (2009). Cooperative learning teori dan aplikasi PAIKEM. Yogyakarta: Pustaka Pelajar.

Sutadipura, S. (1996). Aneka problem keguruan. Bandung: Angkasa.

Syah, M. (2011). Psikologi belajar. Jakarta: Raja Grafindo.

Uno, H.B. (2011). Teori motivasi dan pengukurannya. Cetakan VII. Jakarta: Bumi Aksara. 